Klaudia Miśkowicz, Uczestnictwo i wzajemność. Sposoby funkcjonowania osoby

we wspólnocie w tekstach Karola Wojtyty i Józefa Tischnera, [w:] Cztowiek

w relacji do... Rozważania o cztowieku jako istocie relacyjnej, red. Grzegorz

Wąchol, Kraków 2020, s. 41-53.

DOI: http://dx.doi.org./10.15633/9788374388740.03

MGR KLAUDIA MIŚKOWICZ

\title{
Uczestnictwo i wzajemność. Sposoby funkcjonowania osoby we wspólnocie w tekstach Karola Wojtyły i Józefa Tischnera
}

Chcąc zarysować jak najszerszy obraz rzeczywistości ludzkiej, nie można pominąć kwestii relacji człowieka z innymi. Doświadczenie podsuwa nam stwierdzenie, że osoba żyje wśród innych, wchodzi $\mathrm{z}$ nimi w różne interakcje. $\mathrm{W}$ domu towarzyszą nam najbliżsi, wychodzimy na ulicę i mijają nas przechodnie, w pracy często kooperujemy z innymi, wiele nawet najbardziej zwyczajnych sytuacji życiowych wiąże się $\mathrm{z}$ wchodzeniem w jakieś relacje $\mathrm{z}$ innymi. Różnie ten fenomen opisywali filozofowie. Warto przypomnieć choćby Arystotelesa, który nazwał człowieka istotą społeczną (zoon politikon). Jednakże o ile relacyjność osoby przyjmowana jest powszechnie, o tyle rozumienie tego pojęcia różni się (czasem nawet radykalnie) w koncepcjach poszczególnych myślicieli.

W niniejszym tekście prześledzę, jaki sposób rozumienia wspólnotowego aspektu życia ludzkiego wyłania się z tekstów Karola Wojtyły i Józefa Tischnera. Zestawienie ze sobą myśli tych dwóch polskich filozofów może pomóc ukazać, jak subtelne różnice dzielą czasem na pozór podobne sobie koncepcje. Obaj myśliciele 
stawiali problematykę człowieka na pierwszym miejscu w swoich filozoficznych poszukiwaniach. Przyjrzę się pojęciu uczestnictwa (Karol Wojtyła) oraz pojęciu wzajemności (JózefTischner), które stanowią u tych myślicieli rdzeń rozważań na temat relacji międzyludzkich. Podejmowane zagadnienie rodzi pytanie o to, jak bardzo pojęcie relacyjności należy do istoty człowieka - czy o człowieku można w ogóle myśleć bez odwołania się do jego relacji z innymi lub, mówiąc językiem Wojtyły i Tischnera, bez odwołania się do uczestnictwa i wzajemności.

\section{Osoba jako sprawca czynu w ujęciu Wojtyły}

Właściwe zrozumienie pojęcia relacyjności człowieka u Karola Wojtyły wymaga przyjrzenia się koncepcji człowieka, na której pojęcie to bazuje. Filozofii Wojtyły nie można przypisać jednej tylko etykiety. Wskazuje się na dwa nurty, które ukształtowały jego myślenie. Pierwszym była filozofia św. Tomasza z Akwinu, a z nią tradycja arystotelesowsko-tomistyczna; drugi stanowiła fenomenologia (szczególny wpływ na myśl Wojtyły miały dzieła Maxa Schelera). Czasem wymienia się jeszcze trzeciego autora, którego mistyczne teksty wpłynęły na myśl Wojtyły - św. Jana od Krzyża.

Nie da się teorii uczestnictwa zrozumieć w oderwaniu od koncepcji osoby. Karol Wojtyła uważa, że relacyjny aspekt życia osobowego nie może być prawidłowo zarysowany bez gruntownego zrozumienia osoby w jej dynamice ${ }^{1}$. Na pytanie: „Kim jest człowiek?” Wojtyła odpowiada: „Człowiek jest sprawcą czynu”2. Jeśli

1 Por. K. Wojtyła, Stowo końcowe po dyskusji nad „Osoba i iczynem”, w: K. Wojtyła, Osoba i czyn oraz inne studia antropologiczne, red. T. Styczeń i in., Lublin 2000, s. 366.

2 Por. J. Galarowicz, Paradoks egzystencji etycznej, Kraków 2009, s. 8. 
jest sprawcą, to znaczy, że jest wolny, że sam sobą dysponuje i może zdecydować, jakie czyny podjąć, a jakich zaniechać. Wojtyła wyraźnie odróżnia „czyn” od „uczynnienia”. Ten pierwszy jest efektem wolnego działania człowieka, to drugie natomiast nie jest związane z ludzkim wyborem, uczynnienia po prostu „dzieją się”w człowieku. Czyn to skutek sprawczości osoby; można powiedzieć, że jest jej własnością oraz polem jej odpowiedzialności. Uczynnienie natomiast wynika $z$ wewnętrznego dynamizmu człowieka - człowiek nie przeżywa siebie jako sprawcy, jest bierny, niejako obserwuje to, co samo się z nim dzieje. Za uczynnienia człowiek nie ponosi odpowiedzialności ${ }^{3}$. Jan Galarowicz, wyjaśniając myśl Wojtyły, pisze, że osoba ma charakter substancjalny, co jednak nie znaczy, że jest strukturą statyczną. Wręcz przeciwnie: można powiedzieć, że osoba to nie „rzecz”, a „rzeczywistość” - wieloaspektowa jedność o charakterze dynamicznym ${ }^{4}$. Dynamizm ten wyraża się właśnie w czynach (nie zaś w uczynnieniach). Ponadto Wojtyła poszerza arystotelesowsko-tomistyczne pojęcie osoby, którą wyróżnia rozum i wolna wola, o jeszcze jeden aspekt: sferę świadomościowo-przeżyciową. Człowiek nie tylko jest osobą, nie tylko jest świadom swojego ,ja”, ale również przeżywa siebie jako ,ja”5. O dynamizmie rzeczywistości ludzkiej świadczy przede wszystkim to, że osoba spełnia czyny. Jest nie tylko podmiotem (tego, co się w niej dzieje), ale także sprawcą (to ona decyduje i jest odpowiedzialna za swoje czyny).

Wyjaśnienie znaczenia czynu w analizie sprawczości jest istotne ze względu na Wojtyłowską koncepcję uczestnictwa. Autor Osoby i czynu wychodzi od obserwacji faktu: „człowiek bytuje i działa

3 Por. K. Wojtyła, Osoba i czyn, w: K. Wojtyła, Osoba i czyn oraz inne..., dz. cyt., s. 109-118.

4 Por. J. Galarowicz, Paradoks..., dz. cyt., s. 127.

5 Por. K. Wojtyła, Osoba i czyn, dz. cyt., s. 94. 
wspólnie z innymi”" Swoje czyny spełnia bardzo często nie w samotności, ale właśnie wspólnie z innymi osobami. Czyny spełniane we wspólnocie - stwierdza Wojtyła - też są przecież czynami osoby. Należy więc sytuację współczynienia dokładnie rozważyć i ustalić jej miejsce w koncepcji osoby Wojtyły. Dla Wojtyły fakt współdziałania jest niemożliwy do pominięcia w rozważaniach na temat człowieka. Osoba jest substancją - tym stwierdzeniem Wojtyła wpisuje się w tradycję personalistyczną. Autor Osoby i czynu podkreśla jednak mocno wspólnotowy wymiar życia osobowego człowieka. Być może dlatego Jan Galarowicz przypisuje Wojtyle miano personalisty komunijnego ${ }^{7}$.

Osoba jest sprawcą czynu, ale trzeba wyraźnie zaznaczyć, że samo spełnienie czynu przez osobę już niesie ze sobą wartość. Wojtyła nazywa ją personalistyczną wartością czynu - każdy czyn niesie ze sobą tę wartość, że realizuje się w nim transcendencja osoby, każde działanie bowiem ma charakter samostanowienia, a osoba ujawnia się właśnie przez czyn. W ten sposób osoba spełnia siebie, niejako się aktualizuje ${ }^{8}$. Należy jednak pamiętać, że wartość związana z samym spełnieniem czynu nie jest wartością moralną - jest jednak podstawą dla orzekania o wartościach moralnych. Moralną wartość czynu można określić dopiero po tym, gdy ustali się, czy osoba „spełniła czyn” (czy wybrała go w sposób wolny, czy rzeczywiście jest sprawcą, czy ponosi za czyn odpowiedzialność) ${ }^{9}$.

6 K. Wojtyła, Osoba i czyn, dz. cyt., s. 303.

7 Por. J. Galarowicz, Wprowadzenie do antropologii filozoficznej. Ujęcie fenomenologiczno-personalistyczne, Kęty 2017, s. 268.

8 Por. J. Galarowicz, Wprowadzenie do antropologii..., dz. cyt., s. 305n.

9 Por. J. Galarowicz, Wprowadzenie do antropologii..., dz. cyt., s. 305n. W kwestii relacji personalistycznej wartości czynu do wartości etycznych Wojtyła tak pisze: „Nie jest ona sama [personalistyczna wartość czynu K. M.] jeszcze wartością etyczną, wypływa natomiast z dynamicznej głębi osoby, ujawnia ją i potwierdza, co z kolei pozwala nam także lepiej 
W związku z powyższymi analizami pojawia się pytanie: czy działając wspólnie z innymi, osoba rzeczywiście „spełnia czyn”? Do wyjaśnienia tej kwestii posłużyć może pojęcie uczestnictwa.

\section{I. UCZESTNICTWO}

Karol Wojtyła odróżnia potoczne i filozoficzne znaczenie terminu „uczestnictwo”. Potocznie oznacza ono po prostu „udział”: uczestniczę w spotkaniu, czyli biorę w nim udział. Natomiast filozoficzne znaczenie tego pojęcia sięga samych podstaw owego „udziału”, czyli podstaw, które tkwią w osobie. Wojtyła pisze: „Przez uczestnictwo rozumiemy tutaj to, co odpowiada transcendencji osoby w czynie wówczas, gdy ten czyn jest spełniany «wspólnie z innymi», w różnorodnych relacjach społecznych czy między-ludzkich"10. Przez uczestnictwo człowiek w działaniu „wspólnie z innymi” nie tylko zachowuje jednocześnie personalistyczną wartość swego czynu, ale także urzeczywistnia cel wspólnoty, którą współtworzy. Innymi słowy, dzięki uczestnictwu człowiek ,zachowuje to wszystko, co wynika ze wspólnoty działania, a równocześnie poprzez to właśnie - urzeczywistnia wartość personalistyczną własnego czynu"11. Osoba przez czyn spełnia siebie. Na pytanie, czy działanie „wspólnie z innymi” nie wyklucza się ze spełnieniem siebie, Wojtyła odpowiada jednoznacznie: wykluczenie takie nie występuje, o ile działanie „wspólnie z innymi” przyjmuje charakter uczestnictwa $^{12}$. Podaje też formy wypaczenia uczestnictwa. Pisze o indywidualizmie (dobro jednostki zostaje uznane za naczelne,

zrozumieć wartości etyczne w ich ścisłej odpowiedzialności względem osoby oraz względem całego «świata osób»"(J. Galarowicz, Wprowadzenie do antropologii..., dz. cyt., s. 307).

10 J. Galarowicz, Wprowadzenie do antropologii..., dz. cyt., s. 309.

11 J. Galarowicz, Wprowadzenie do antropologii..., dz. cyt., s. 309.

12 Por. J. Galarowicz, Wprowadzenie do antropologii..., dz. cyt., s. 310. 
a wspólne działanie z innymi uważa się za przykrą konieczność, takie działanie bowiem w jakiś sposób ogranicza jednostkę, dobro innych stanowi tutaj ograniczenie dla dobra jednostki) i totalizmie (jednostkowość zostaje uznana za wroga wspólnoty, uznaje się człowieka za niezdolnego do uczestnictwa i dążenia do wspólnego dobra, dlatego cele wspólnoty można osiągnąć jedynie przez radykalne ograniczenia nałożone na jednostki $)^{13}$.

Widać wyraźnie, że w myśli Wojtyły wspólne działanie z innymi osobami stanowi istotny rys człowieka. Filozof stwierdza, że „uczestnictwo jest poniekąd właściwością osoby działającej i bytującej wspólnie $z$ innymi" ${ }^{14}$. To stwierdzenie pozwala przyporządkować koncepcję Wojtyły do personalizmu komunijnego, nie zaś klasycznego. Jednak co znaczą słowa, że uczestnictwo jest właściwością osoby? Tę zagadkę rozjaśnić pomoże kolejny fragment $z$ tekstu Wojtyły pt. Osoba: podmiot $i$ wspólnota:

Nie chodzi tutaj o konstytuowanie się [ludzkiego ,ja” - K. M.] w znaczeniu metafizycznym, gdyż w tym znaczeniu każde ja jest ukonstytuowane we własnym suppositum. Natomiast konstytuowanie się konkretnego ,ja” w jego osobowej podmiotowości dokonuje się w sposób szczególny przez działanie i bytowanie „wspólnie z innymi” we wspólnocie społecznej, w wymiarze różnych „my”'15.

Z zacytowanych słów wynika, że uczestnictwo jest nieodłącznym elementem rzeczywistości ludzkiej, że mówienie o człowieku tylko jako o jednostce stanowi rodzaj wypaczenia i nie pozwala w pełni objąć jego natury. Osoba staje się sobą także dzięki

13 Por. J. Galarowicz, Wprowadzenie do antropologii..., dz. cyt., s. 313n.

14 K. Wojtyła, Uczestnictwo czy alienacja?, w: K. Wojtyła, Osoba i czyn, dz. cyt., s. 459.

15 K. Wojtyła, Osoba:podmiot i wspólnota, w: K. Wojtyła, Osoba i czyn, dz. cyt., s. 404. 
funkcjonowaniu we wspólnocie, jeśli funkcjonowanie to odbywa się w ramach uczestnictwa. Co więcej, przez uczestnictwo osoba urzeczywistnia się jako podmiot w sposób pełny ${ }^{16}$.

\section{Osoba jako uczestnik dramatu w ujęciu Tischnera}

O ile filozofii Wojtyły blisko było do tradycji arystotelesowsko-tomistycznej (choć nie brakowało w niej nowatorskich rozstrzygnięć wykraczających poza obręb tej tradycji), o tyle Tischner starał się na ten nurt spoglądać krytycznie (efektem tego były liczne polemiczne artykuły). Na ukształtowanie się jego myśli wielki wpływ miały teksty współczesnych filozofów (m.in. Georga Wilhelma Friedricha Hegla, Sørena Kierkegaarda, Martina Heideggera, Edmunda Husserla, Emmanuela Lévinasa), z którymi starał się dyskutować i z których czerpał inspirację. Najczęściej przypisuje się myśl Tischnera do nurtu filozofii dialogu, a konkretnie uznaje się go za twórcę filozofii dramatu. Można się spotkać także z opiniami, że jego koncepcja jest oryginalnym personalizmem ${ }^{17}$.

Kim jest człowiek w ujęciu Tischnera? „Człowiek to istota dramatyczna" - odpowiada filozof ${ }^{18}$. Znaczy to, że jednostka jest tworzona przez dramat, w którym uczestniczy. Tischner zadaje pytanie, jaka musi być konstrukcja człowieka, by mógł on brać udział w dramacie. W Filozofii dramatu czytamy: „Być istotą dramatyczną znaczy: przeżywać dany czas, mając wokół siebie innych ludzi

16 Por. K. Wojtyła, Osoba: podmiot i wspólnota, dz. cyt., s. 407.

17 Takie stwierdzenie wysuwa np. Jan Galarowicz (por. J. Galarowicz, $\mathrm{Pa}$ radoks..., dz. cyt., s. 303).

18 Por. J. Tischner, Zarys fllozofii cztowieka dla duszpasterzy i artystów, Kraków 1991, s. 7. 
i ziemię jako scenę pod stopami"19. Te trzy elementy są kluczowe. Czas dramatyczny to czas, który dzieje się „między nami” - nie ma nic wspólnego z obiektywnym czasem matematycznego przyrodoznawstwa, ale wiąże ze sobą uczestników dramatu, wyznacza następstwa ich spotkań i rozstań, jest niejako „substancją” drama$t^{20}$. Obok czasu znajduje się również przestrzeń, którą Tischner nazywa sceną dramatu. To oryginalne porównanie przestrzeni pod stopami do sceny pozwala filozofowi zwrócić uwagę na kolejny istotny element dramatu: scena jest przede wszystkim przestrzenią, na której odbywają się spotkania, a także rozstania. Najważniejszą cechą opisującą człowieka jako istotę dramatyczną jest otwarcie na drugiego człowieka. Świat, w którym żyjemy, jest światem pełnym ludzi. Każdy z nich może stać się uczestnikiem mojego dramatu. Znakiem wskazującym na moment rozpoczęcia wspólnego wątku dramatycznego Tischner uczynił „pytanie”: drugi zadaje pytanie i w ten sposób otwiera się na mnie i daje mi szansę otwarcia się na niego. Tak właśnie wygląda dramatyczna rzeczywistość: spotykam innych ludzi, uczestników dramatu, na scenie, która jest jakby podłożem naszych spotkań, oraz w czasie wyznaczającym porządek spotkań i rozstań ${ }^{11}$. Być istotą dramatyczną znaczy więc: żyć w taki sposób, że bierze się udział w dramacie. Tischner pisze nawet, że do natury człowieka należy czas dramatyczny oraz dwa otwarcia: intencjonalne otwarcie na scenę oraz dialogiczne otwarcie na drugiego człowieka ${ }^{22}$. Ponadto człowiek jako istota dramatyczna wie, że to w jego rękach jest jego zguba lub ocalenie. To sprawia, że jednostka kieruje swoim życiem tak, by uniknąć zguby, a dojść do ocalenia. Tak pojęty człowiek jest właśnie podmiotem dramatu.

19 J. Tischner, Filozofia dramatu, Kraków 2012, s. 7.

20 Por. J. Tischner, Filozofia dramatu, dz. cyt., s. 8.

21 Por. J. Tischner, Filozofia dramatu, dz. cyt., s. 8n.

22 Por. J. Tischner, Filozofia dramatu, dz. cyt., s. 9n. 


\section{I. KONCEPCJA WZAJEMNOŚCI}

Pytając o to, co oznacza „relacyjność” człowieka w filozofii Tischnera, nie da się pominąć kwestii wzajemności. To pojęcie wprowadza nas w sam środek Tischnerowskiej filozofii dramatu. Czym jest wzajemność? Tischner pisze: „Wzajemność oznacza, że jesteśmy, jacy jesteśmy, poprzez siebie. To p o p r ze z znaczy: możemy siebie obwiniać lub możemy być sobie wdzięczni” ${ }^{23}$. W innym tekście możemy przeczytać: „Wzajemność jest zapośredniczającym przez wartość in n e g o rozpoznawaniem i ustanawianiem własnej wartości oraz jednoczesnym rozpoznawaniem oraz ustanawianiem wartości in ne g o poprzez moją własną wartość"24. Oba fragmenty wskazują jednoznacznie na jakieś splecenie się rzeczywistości spotykających się osób. Ich spotkanie dokonuje gruntownego prze-istoczenia „ja” i „ty”. Tischner pisze, że drugi wkracza jak drzazga w moją przestrzeń wewnętrzną - wkracza we mnie, a nie tylko pojawia się obok mnie ${ }^{25}$. Owo prze-istoczenie może polegać na tym, że moja świadomość, również moje przeżycia w pewnym sensie zmieszały się ze świadomością i przeżyciami drugiego. Dokonała się w nas przemiana, której nie byłoby, gdybyśmy się nie spotkali i nawzajem nie „wkroczyli w siebie”. I to może być właśnie znaczenie owego „poprzez siebie”, o którym pisze Tischner we fragmencie o wzajemności. Filozof wskazuje również na pewien paradoks wzajemności: polega ona na tym, że daję drugiemu to, co bez niego nie istnieje. Pisze: „Osoby wzięte oddzielnie mają puste ręce. Dopiero wzajemność czyni je bogatymi dla siebie”26. Widać wyraźnie, że dzięki wzajemności pojawia się jakaś nowa jakość między ludźmi.

23 J. Tischner, Filozofia dramatu, dz. cyt., s. 101.

24 J. Tischner, Inny. Eseje o spotkaniu, Kraków 2017, s. 83.

25 Por. J. Tischner, Inny, dz. cyt., s. 43.

26 J. Tischner, Krótki przewodnik po życiu, Kraków 2017, s. 42. 
Każdy jest wzbogacony o to, czego nie mógłby otrzymać, gdyby nie spotkanie z drugim. Dzięki wzajemności moje „ja” zostaje w pewien sposób poszerzone.

Wzajemność sprawia, że zarówno ja, jak i ty możemy poznać prawdę o sobie - istotnym rysem filozofii Tischnera jest to, że prawdę tę poznajemy poprzez siebie i dzięki sobie. Chodzi o to, bym ja patrzył na świat nie tylko swoimi oczyma, ale również twoimi, a ty moimi. Jak stwierdza filozof: „Pełna prawda jest owocem wspólnych doświadczeń - twoich o mnie, a moich o tobie"27. Można więc powiedzieć, że człowiek nie potrafi siebie w pełni zrozumieć w samotności, że rozumienie to może być poszerzone dzięki spotkaniu z drugim. Człowiek w samotności, bez relacji, człowiek jako monada nie rozwija w pełni swojego człowieczeństwa. Dopiero we wzajemności zostaje dopełniony tym, czego nie mógł osiągnąć bez drugiego. Takie wzajemne dopełnianie się jest swoistym ciężarem. Tischner pisze: „Nie ma Ja bez Ty i Ty bez Ja. Znaczy to nie tylko, że Ja i Ty odbijamy się wzajemnie, jak lustra, stojące na przeciwległych brzegach rzeki, ale i to, że Ty jesteś we mnie, a Ja w tobie, i że niesiemy siebie jako swe ci ięża r y"28. Nie chodzi więc tylko o to, że drugi pozwala mi zrozumieć siebie, ale też o to, że staje się częścią mnie, a ja staję się jego częścią. W jakiś sposób się współkonstytuujemy.

$\mathrm{Z}$ powyższych rozważań zdaje się wynikać, że Tischnerowska koncepcja osoby jest rzeczywiście taka jak w filozofii dialogu, w której przyjmuje się, że ,ja” konstytuuje się przez „ty”. W Filozofii dramatu, w której mowa jest o tym, że nie ma „ty” bez ,ja” oraz „ja” bez „ty”, Tischner zapisuje: „Jesteś we mnie. Jestem w tobie. [...] Mimo tego przenikania jesteśmy sobą. Sobą do końca. Sobą nie do zmazania"29. Wzajemne przenikanie nie prowadzi do jakiegoś

27 J. Tischner, Etyka solidarności, Kraków 2018, s. 22.

28 J. Tischner, Filozofia dramatu, dz. cyt., s. 108.

29 J. Tischner, Filozofia dramatu, dz. cyt., s. 108. 
zamazania czy rozpłynięcia się ,ja” w „ty”. Prowadzi jedynie do mojego utwierdzenia się w moim ,ja” i twojego potwierdzenia się w twoim ,ja”.

Mimo tego, że drugi może radykalnie wpłynąć na kształtowanie się mojego człowieczeństwa, nie jest on zdolny zmienić mnie bez mojego w tym udziału. To ja muszę zdecydować się na otwarcie, to ja muszę udzielić odpowiedzi na pytanie drugiego. Tischner zaznacza, że tylko człowiek jest panem swoich aksjologicznych uznań; nawet jeśli zło czy dobro przychodzą do niego poprzez drugiego, to nie są w stanie go zniszczyć czy zbudować, jeśli on sam ich nie wybierze. To człowiek sam „rodzi siebie” (w swoim człowieczeństwie) i nawet jeśli odbywa się to za sprawą drugiego, nie byłoby możliwe bez udziału woli człowieka. W tej perspektywie słowa „stawać się poprzez drugiego" zdają się mieć łagodniejszy wydźwięk. Owszem, bez drugiego nie mógłbym w pełni być sobą, ponieważ to spotkanie $z$ drugim aktywizuje we mnie pewne struktury i moce, ale jednocześnie nie byłbym sobą, gdybym nie wyraził zgody na przyjęcie pewnych wartości, na to, by one mnie budowały ${ }^{30}$.Zło nie jest w stanie człowieka zniszczyć, jeśli ten go nie przyjmie; dobro nie jest w stanie człowieka ocalić, jeśli ten je odrzuci.

Zdaniem Tischnera człowiek w jakimś sensie nadal byłby sobą bez drugiego, miałby zdolność do podejmowania decyzji, byłby oczywiście podmiotem swoich czynów. Jednakże jego człowieczeństwo może się objawić w pełni tylko poprzez spotkanie $z$ drugim. Człowiek jest bowiem istotą dramatyczną, a to znaczy, że jest on m.in. otwarty na drugiego człowieka i ku niemu skierowany, że to otwarcie stanowi o jego istocie. Otwarcie na drugiego i obecność drugiego wpływają na kształtowanie się człowieczeństwa człowieka, na budowanie się jego „ja”, ale nie można zapomnieć, że kształtowanie to odbywa się za przyzwoleniem człowieka i z jego

30 Por. J. Galarowicz, Paradoks..., dz. cyt., s. 354. 
niezaprzeczalnym udziałem. Jan Galarowicz stwierdza, że koncepcja Tischnera jest oryginalnym personalizmem. Nazywa go personalizmem dialogicznym ${ }^{31}$.

\section{Podsumowanie}

Mimo wyraźnych różnic co do metody uprawiania filozofii i punktu wyjścia rozważań o człowieku z myśli obydwóch filozofów można wyprowadzić podobne wnioski. Karol Wojtyła kładzie duży nacisk na ukazanie, że relacyjność człowieka ma istotny wpływ na kształtowanie się jego człowieczeństwa. Człowiek, żyjąc i działając nie tylko „obok innych”, ale przede wszystkim „wspólnie z innymi”, spełnia siebie. Józef Tischner, budując swoją koncepcję człowieka, wydaje się świadom istnienia zarzutów wysuwanych wobec filozofii dialogu dotyczących niebezpieczeństwa rozmycia ,ja”, roztopienia go w „ty”, zamazania w intersubiektywności. Człowiek Tischnera to jednostka - osoba, której nieodłącznym składnikiem jest otwartość na drugiego. Otwartość ta wpisana jest niejako w „substancję” osoby.

Nie jest łatwo znaleźć wspólnego języka dla zestawienia koncepcji obu myślicieli. Przyczynia się do tego odrębność wybranych przez nich metod. Koncepcja Wojtyły, mimo że mocno przesiąknięta językiem tradycji arystotelesowsko-tomistycznej (z jej skupieniem na bycie, substancji, z językiem silnie ontologizującym), wychodzi naprzeciw ludzkiemu doświadczeniu spotkania. Być może jest to efekt zetknięcia się filozofa $\mathrm{z}$ fenomenologią zwracającą się do ludzkich doświadczeń, a być może także z pismami św. Jana od Krzyża, w których Bóg przedstawiany jest jako „Ty” wychodzące na spotkanie człowiekowi. Natomiast język filozofii Tischnera daleko odbiega od klasycznego języka metafizyki; myśliciel świadomie się

31 Por. J. Galarowicz, Paradoks..., dz. cyt., s. 344. 
go wyrzeka, aby móc uczynić opis rzeczywistości ludzkiej bardziej źródłowym. Uważa bowiem, że język klasycznej metafizyki, choć przydatny w badaniu świata, nie nadaje się do wnikania w tajemnicę osoby. Dzieje się tak za sprawą rozbieżnych otwarć potrzebnych do badania tych dwóch rzeczywistości: otwarcia intencjonalnego wobec świata rzeczy i otwarcia dialogicznego wobec innych osób.

Jan Galarowicz obu filozofom nadaje miano personalistów dialogicznych ${ }^{32}$. Obaj bowiem rdzeniem swojej filozofii uczynili osobę, której przyznają niepodważalną i niezbywalną wartość pośród świata rzeczy. Obaj również wyraźnie podkreślają wątek relacyjności jako konieczny do właściwego zrozumienia tajemnicy człowieka. Mimo odmienności tych koncepcji schodzą się one więc w jednym punkcie, a punktem tym jest człowiek i jego wymiar dialogiczny.

\section{Wybrana bibliografia}

1. Galarowicz J., Paradoks egzystencji etycznej, Kraków 2009.

2. Galarowicz J., Wprowadzenie do antropologii filozoficznej. Ujęcie fenomenologiczno-personalistyczne, Kęty 2017.

3. Tischner J., Zarys flozofi cztowieka dla duszpasterzy i artystów, Kraków 1991.

4. Wojtyła K., Osoba i czyn, w: K. Wojtyła, Osoba i czyn oraz inne studia antropologiczne, red. T. Styczeń i in., Lublin 2000, s. 71-414.

32 Por. J. Galarowicz, Paradoks..., dz. cyt., s. 132, 346. 
A/4 Uniwersytet Papieski

Tfon Jana Pawla II 